\title{
Users Attitude Towards the Use of Library Catalogue in Federal University of Kashere Library in Gombe State, Nigeria
}

\author{
Mohammed Abubakar Dukku, Andrew Temboge* \\ University Library, Federal University of Kashere, Kashere, Nigeria \\ Email address: \\ mohabzaz17@gmail.com (M. A. Dukku), atemboge@yahoo.com (A. Temboge), temtsandza@gmail.com (A. Temboge) \\ ${ }^{*}$ Corresponding author
}

\section{To cite this article:}

Mohammed Abubakar Dukku, Andrew Temboge. Users Attitude Towards the Use of Library Catalogue in Federal University of Kashere Library in Gombe State, Nigeria. American Journal of Information Science and Technology. Vol. 3, No. 4, 2019, pp. 91-97.

doi: $10.11648 /$ j.ajist.20190304.12

Received: October 29, 2019; Accepted: November 22, 2019; Published: December 2, 2019

\begin{abstract}
The study investigated the awareness and use of library catalogue for accessing information resources by users of Federal University of Kashere (FUK) Library. Four research questions guided the study. Survey research design was used, registered users of the University Library between 2016-2019 numbering 920 formed the population of the study where a sample of 272 (30\% sample) was used based on 95\% confidence level and 5\% confidence interval of Sample Size Calculator. The instrument used for data collection was questionnaire. Data generated was analyzed using simple percentage and descriptive statistics. The findings of the study revealed that majority of the respondents were aware of library catalogue existence; they were more informed about card catalogue usage than OPAC for retrieving information resources. In effect, the respondents use card catalogue regularly compared to the OPAC. Majority of the respondents used the library for research work rather than for leisure and recreational purposes. Poor computer skills hindering navigation when searching OPAC and inability to locate materials on the shelves, indicated in the catalogue as being available were the challenges affecting the use of catalogue as an information retrieval tools. The study recommended that the library management should organize a periodic user education, orientation and sensitization programmes for the undergraduate users to create awareness and enable them gain the needed skills to use the library catalogue maximally when searching for information resources. Guidelines on how to use catalogue and library in general should be prepared and issued to registered users. Regular shelf reading should be done so as to establish right contact between library users and library materials.
\end{abstract}

Keywords: Card Catalogue, Information Resources, Library, OPAC, Use and Users

\section{Introduction}

The university library goals and objectives are to provide adequate and relevant information resources both in print and online for university community to support teaching, learning and research (these for undergraduates students may refer to class work, assignments, research/project work, term papers, seminar presentation by providing relevant information and services provision for effective and efficient achievement of academic pursuit). University library provides well stocked information resources and trained personnel to organize available information materials and assist faculty members and student users in the retrieval and use of these resources.

\subsection{Review of Related Literature}

The library as a service oriented organization must provide the bibliographic resources and services channeled towards the fulfillment of its parent institution's goals and objectives. The library ensures that the resources acquired are well organized to allow easy access by the library users [1]. The traditional goals and objectives of the library catalogue are to enable users to search a library's collection to find items pertaining to specific titles, authors, or subjects. Library catalogue is considered as an interface of information retrieval system which assists information searchers to access resources of libraries using several access points. 
Library catalogue exist in different form. Like the card catalogues, sheaf catalogues, books, machine readable catalogues (MARCs) and online public access catalogues (OPACs). Libraries were traditionally known to provide access to library information materials through card catalogues and book catalogue as the primary information locating tools. Following advancement in ICT and subsequent development of Online Public Access Catalogue (OPAC), the traditional concept of access to library resources which many scholars identified to be prone to numerous challenges has changed. OPAC has brought a changing relationship between libraries and their users in the changing ICT environment. Library OPACs first emerged in the late 1970s and early 1980s and have gone through several cycles of change and development all geared towards improvement. The library OPAC as an automated catalogue system was developed as a tool to locate those information resources that had been acquired, organized and preserved by the library itself. In this environment, the user is both the primary searcher of the system and the user of the information resources [2]. Online public access catalogue (OPAC) is the most modern form of library catalogue, whereby bibliographic records of all the documents collection are stored in the computer memory or server. As a means of ensuring that information materials are available and accessible, libraries provide catalogues to display what is available in the library and where they can be obtained [3].

Awareness of OPAC and its interface features is $100 \%$ majority of respondents $66.7 \%$ stated that speed of navigation was fast, $76.7 \%$ reported that library OPAC has no multimedia Interface like video, rear players and audio features. Overall majority of respondents $80 \%$ satisfied with OPAC functionality [4]. Again, awareness of the library catalogue is the ability of the students to have communication and consciousness of its essence, its retrieval technique as well as their relevance to the information user. Students' skills in search catalogue can be created through library tours, orientations, seminars, lectures, library staff, handbooks and use of library studies. Although, much awareness of the retrieval tools may be created in the libraries, it does not necessarily mean its accessibility, not to speak of its use. The major importance is that they help library users to locate and retrieve the information materials they need [5].

KumarandVohra investigated the use of Online Public Access Catalogue by the users at Guru Nanak Dev University Library, Amritsar (Punjab) and discovered that majority of the respondents $68.7 \%$ were not aware regarding OPAC, $12.5 \%$ stated the reason to be lack of assistance from library staff and slow speed. The purpose of using OPAC majority of the respondents $63.2 \%$ stated that they use OPAC to know the availability of required document. The study suggests that the users should be made familiar with the use and operation of the OPAC by providing special training [6].

Kumar revealed that $26.99 \%$ respondents use the OPAC fortnightly and $22.84 \%$ weekly. $61.59 \%$ use the OPAC to locate a document on shelves and $58.48 \%$ to know the particular book is available on the shelves or not, $37.71 \%$ to know the bibliographical details, 31.14\%. 91\% respondents used the title search approach and $83.04 \%$ used the author search approach, User also indicated that the information regarding the problem faced by the respondents while using the OPAC like $74.39 \%$ faced by the problem lack of proper guidance about OPAC followed by $67.47 \%$ lack of awareness, $36.33 \%$ satisfied with the OPAC and its services [7]. If a user lacks skills to use a library catalogue, the user may not be able to make effective use of the library resources. The studies of Oghenekaro found that users exhibit patterns of library catalogue usage, that education, experience and sophistication of library users determine the pattern or level of library catalogue use [1].

Consequently, AmkpaandIman emphasized that the success or failure of students to locate resources in the library depends on the skill acquired though the library instruction progamme [8]. This is important because, in spite of the benefits which students can derive from catalogue use, its use is still poor in Nigerian university libraries. Okorafor discovered that catalogue use in Latunde Odeku Medical Library was poor. The author attributed the reason for the poor usage to lack of user education programme [9]. Aguolu andAguolu observed that students use catalogue mostly for educational purposes and have really helped in conducting and disseminating information resources in the library [10]. In essence, students use the catalogue to enable them conduct research in the library. While this is a welcome development, it is important to occasionally assess the effectiveness of the library catalogue especially from the users' point of view. It is on this note that this study investigates the use of library catalogue by undergraduate student in the university library.

\subsection{Statement of the Problem}

For any academic library to serve the purpose to which it is created as agent of information provider in educational environment. It must contain different types of materials, very rich in nature, comprehensive in coverage with adequate bibliographical tools describing the location of each item, which is significant to the whole concept of library and librarianship. However, it is observed sometimes that the bibliographic tools that supposed to lead or guides user to the location of a particular item in the library are either found in adequate, misleading, totally not provided or somehow incomplete. The consequences of this, a user may end off scanning from one shelve to another in search of a document, which is often a waste of time or failure to locate and retrieve the needed material. Therefore, the study investigates the access and use of library catalogue by students of Federal University of Kashere, Gombe State.

\subsection{Research Objectives}

The study is designed to achieve the following objectives:

a. To find out the students awareness about library catalogue as access point to library collection.

b. To find out methods employ by students to consult 
library catalogue to search for information resources.

c. To ascertain the extent of use of the library catalogue by students to access information resources.

d. To identify the constraints associated with the use of library catalogue.

\subsection{Research Questions}

The study is designed to answer the following research questions:

a. What is the student's awareness about library catalogue as access point to library collection?

b. What are the methods employ by students to consult library catalogue to search for information resources in FUK?

c. To what extent do students use library catalogue in FUK?

d. What are the constraints associated with use of library catalogue in FUK?

\section{Methodology}

The survey research method was adopted for the study, and questionnaire was the instruments use for collecting data. The total population of the study comprises is 920 undergraduate students that had registered with the University Library with effect from 4/1/2017 to $15 / 7 / 2019$, covering 3 academic sessions. The stratification sampling technique was employed to sample the entire registered population of undergraduate library users from each level (100-500) in Federal University of Kashere respectively. Thus, 272 respondents were selected for the study based on 95\% confidence level and 5\% confidence interval of Sample Size Calculator. However, out of 272 questionnaires that were distributed, the same 272 were returned and 262 were found useful because 10 respondents indicated not aware of the subject. The completed and returned questionnaires were analyzed using descriptive statistics, percentage and frequency distribution.

\section{Analysis and Discussion of the Findings}

\subsection{The Gender of the Respondents}

This section presents questionnaire collected on the basis of gender of the research respondents. The gender breakdown is presented on Table 1 .

Table 1. The Gender of the Respondents $(N=272)$.

\begin{tabular}{llllll}
\hline Level & Male & \% & Female & \% & Total \\
\hline 100 & 38 & 68 & 18 & 32 & 56 \\
200 & 32 & 64 & 18 & 36 & 50 \\
300 & 38 & 73 & 14 & 27 & 52 \\
400 & 42 & 72 & 16 & 28 & 58 \\
500 & 38 & 68 & 18 & 32 & 56 \\
Total & 188 & 69 & 84 & 31 & 272 \\
\hline
\end{tabular}

Key: $\%=$ Percentage.
The question on the demographic information of the respondents was on gender presented in Table 1. It shows that majority of the respondents $188(69 \%)$ were male, followed by females $84(31 \%)$. This shows that majority of library users in the Federal University of Kashere Library were male. This implies that the male ranked highest in utilizing the library catalogue more than the female. This finding is in agreement with Clifford \& Zaccus whose study on "users attitude towards the use of library catalogue in two selected University Libraries in South West Nigeria" revealed that number of the male respondents is higher than female respondents[11].

\subsection{User Awareness of Library Catalogue}

Librarians in discharging their responsibilities should inform library users by communicating the availability of new technology and the way it operates to them.

Table 2. Awareness of Library Catalogue $(N=272)$.

\begin{tabular}{llllll}
\hline Level & YES & \% & NO & \% & Total \\
\hline 100 & 50 & 92.6 & 4 & 7.4 & 54 \\
200 & 44 & 88 & 6 & 12 & 50 \\
300 & 54 & 100 & 0 & 0 & 54 \\
400 & 56 & 100 & 0 & 0 & 56 \\
500 & 58 & 100 & 0 & 0 & 58 \\
Total & 262 & 96.3 & 10 & 3.7 & 272 \\
\hline
\end{tabular}

Key: $\%=$ Percentage.

Table 2 revealed that majority of the respondents 262 $(96.3 \%)$ were aware of the existence of the library catalogue in the university library. This finding is a good development for the library because it shows that the methods they used for creating awareness of library yielded good results. Awareness of access points to library collections are the most important factors influencing the success of the retrieval and utilization of library resources. The awareness of respondents would depend on the way the library informs their users about the use and functions of library catalogue revealing the available resources and its location in the library. This findings correspond with that of Oghenekaro on the "use of library catalogue in Nigerian University Libraries: A focus on Redeemer's University Library", that majority of respondents $225(89.6 \%)$ were aware of the existence of catalogue in the library [1].

Table 3. Types of Catalogue Users were aware of. $(N=262)$.

\begin{tabular}{llllllll}
\hline \multirow{2}{*}{ Level } & \multicolumn{2}{l}{ Card Catalogue } & \multicolumn{2}{l}{ OPAC } & \multicolumn{2}{c}{ Book Catalogue } & \multirow{2}{*}{ Total } \\
\cline { 2 - 6 } & A & \% & B & \% & C & \% & \\
\hline 100 & 26 & 52 & 10 & 20 & 14 & 28 & 50 \\
200 & 30 & 68 & 6 & 14 & 8 & 18 & 44 \\
300 & 48 & 89 & 0 & 0 & 6 & 11 & 54 \\
400 & 24 & 43 & 2 & 4 & 30 & 54 & 56 \\
500 & 50 & 86 & 8 & 14 & 0 & 0 & 58 \\
Total & 178 & 68 & 26 & 10 & 58 & 22 & 262 \\
\hline
\end{tabular}

Key: $\mathrm{F}=$ Frequency, $\%=$ Percentage.

Table shows that majority of the respondents $178(68 \%)$ were aware of the card catalogues as a access point / retrieval 
tool for searching for information resources in the library. With $64 \%$ response rate it is obvious that the respondents are aware of the existence of the card catalogues as a retrieval tool for searching for information materials. $26(10 \%)$ of the respondents were aware of the existence of OPAC as a retrieval tools in the library. This indicates that majority of the respondents were not aware of online public access catalogue in the library and they only use manual catalogue for information retrieval. This development is not healthy for university library in the $21^{\text {st }}$ century, where information resources should accessed from different locations within and outside the university using modern ICT facilities like OPAC.

\subsection{Sources of User Awareness of Library Catalogue}

In order to find out how respondents became aware of the library catalogue in the university library, options were provided in the questionnaire on the sources of library catalogue and they were asked to indicate the sources of their awareness. Their responses were presented in the Table 4 below.

Table 4. Sources of Awareness ( $N=262)$.

\begin{tabular}{|c|c|c|c|c|c|c|c|c|c|c|c|}
\hline \multirow[t]{2}{*}{ Level } & \multicolumn{2}{|c|}{ University website } & \multicolumn{2}{|c|}{ library staff } & \multicolumn{2}{|c|}{ Notice board } & \multicolumn{2}{|c|}{ Library Orientation } & \multicolumn{2}{|c|}{$\begin{array}{l}\text { User education } \\
\text { Programmes (GST) }\end{array}$} & \multirow[t]{2}{*}{ Total } \\
\hline & $\mathbf{F}$ & $\%$ & $\mathbf{F}$ & $\%$ & $\mathbf{F}$ & $\%$ & $\mathbf{F}$ & $\%$ & $\mathbf{F}$ & $\%$ & \\
\hline 100 & 8 & 16 & 12 & 24 & 2 & 4 & 12 & 24 & 16 & 32 & 50 \\
\hline 200 & 8 & 18 & 2 & 5 & 0 & 0 & 8 & 18 & 26 & 59 & 44 \\
\hline 300 & 6 & 11 & 10 & 19 & 0 & 0 & 8 & 15 & 30 & 56 & 54 \\
\hline 400 & 2 & 4 & 36 & 64 & 0 & 0 & 2 & 4 & 16 & 29 & 56 \\
\hline 500 & 12 & 21 & 46 & 79 & 0 & 0 & 0 & 0 & 0 & 0 & 58 \\
\hline
\end{tabular}

Key: $\mathrm{F}=$ Frequency, $\%=$ Percentage.

Table 5 reveals that $106(40 \%)$ got their awareness through library staff, followed by those that knew it through the user education programme (GST) 88 (16\%). The finding of the study reveals that the creation of awareness on use of catalogue through library orientation, university website and notice board is significantly low. This implies that majority of respondents became aware of information retrieval tools through library staff and user education programmes these are more formal sources of awareness about library catalogue function and use. The result proves that the management of the university library provides awareness opportunity to users for retrieval and utilization of information resources, except that they need to put more emphasis during library orientation to add to existing ones. Again, university website could be used to provide access to library resources especially e-resources, therefore library management need to make it as one of the major access points and retrieval of information resources.

\subsection{Use Patterns of Library Catalogue}

The study sought to find out the catalogue use patterns of respondents, the options were given for the users to choose which is applicable to them.
Table 5. Use Patterns of Library Catalogue $(N=262)$.

\begin{tabular}{llllllll}
\hline \multirow{2}{*}{ Level } & \multicolumn{2}{l}{ Regularly } & \multicolumn{2}{l}{ Occasionally } & \multicolumn{2}{l}{ Never } & \multirow{2}{*}{ Total } \\
\cline { 2 - 6 } & F & \% & F & \% & F & \% & \\
\hline 100 & 20 & 40 & 28 & 56 & 2 & 4 & 50 \\
200 & 14 & 32 & 20 & 45 & 10 & 23 & 44 \\
300 & 24 & 44 & 20 & 37 & 10 & 19 & 54 \\
400 & 42 & 75 & 12 & 21 & 2 & 4 & 56 \\
500 & 58 & 100 & 0 & 0 & 0 & 0 & 58 \\
Total & 158 & 60 & 80 & 31 & 24 & 9 & 262 \\
\hline
\end{tabular}

Key: $\mathrm{F}=$ Frequency, $\%=$ Percentage.

Table 5 indicated that majority of the respondents 158 $(60 \%)$ used the library catalogue regularly when searching for materials in the library. 24 (9\%) of the respondents never used the catalogue but they were aware of it existence in the library as indicated on table 2 above. This shows that these few users preferred browsing the shelves to search for information resources. The finding of this study however revealed that the rate at which the respondents used the library catalogue regularly was very high. This finding is contrary to that of Oghenekaro whose study found low usage of the library catalogue attributed the low frequency of use to lack of user education programmes [1].

Table 6. How Users Retrieve Information Resources.

\begin{tabular}{|c|c|c|c|c|c|c|c|c|c|c|c|c|c|}
\hline \multirow[t]{2}{*}{ Level } & \multicolumn{2}{|c|}{$\begin{array}{l}\text { Through Card } \\
\text { Catalogue }\end{array}$} & \multicolumn{2}{|c|}{ Through OPAC } & \multicolumn{2}{|c|}{ Staff Assistance } & \multicolumn{2}{|c|}{$\begin{array}{l}\text { Browsing the } \\
\text { Shelve }\end{array}$} & \multicolumn{2}{|c|}{ Ask Friends } & \multicolumn{2}{|c|}{ Ask Colleagues } & \multirow[t]{2}{*}{ Total } \\
\hline & $\mathbf{F}$ & $\%$ & $\mathbf{F}$ & $\%$ & $\mathbf{F}$ & $\%$ & $\mathbf{F}$ & $\%$ & $\mathbf{F}$ & $\%$ & $\mathbf{F}$ & $\%$ & \\
\hline 100 & 10 & 20 & 0 & 0 & 6 & 12 & 28 & 56 & 6 & 12 & 0 & 0 & 50 \\
\hline 200 & 10 & 23 & 6 & 14 & 10 & 23 & 16 & 36 & 2 & 5 & 0 & 0 & 44 \\
\hline 300 & 10 & 19 & 6 & 11 & 14 & 26 & 12 & 22 & 6 & 11 & 6 & 11 & 54 \\
\hline 400 & 14 & 25 & 0 & 0 & 36 & 64 & 6 & 11 & 0 & 0 & 0 & 0 & 56 \\
\hline 500 & 2 & 3 & 0 & 0 & 54 & 93 & 2 & 3 & 0 & 0 & 0 & 0 & 58 \\
\hline
\end{tabular}


The finding indicated poor use of OPAC $12(5 \%)$ at the university library. This finding is in agreement with Fabunmi \& Asubiojo whose study on OPAC use by students of Obafemi Awolowo University, Ile-Ife found out that though many students were aware of the OPAC, few actually made use of it. The study found that majority of the respondents were aware of library catalogue in the library including OPAC [12]. The finding in this case was surprising considering that majority of the respondents had indicated that they do not use the OPAC. The reason for this could be attributed to the fact that users did not have the ICT skills to manipulate the OPAC and they solicit the help of library assistants or even friends to retrieve information materials in the library. Lack of skills could discourage users from using the catalogue.

Table 7. The Purpose of Using Library Catalogue.

\begin{tabular}{|c|c|c|c|c|c|c|c|c|c|}
\hline \multirow[t]{2}{*}{ Level } & \multicolumn{2}{|c|}{$\begin{array}{l}\text { To Access Research } \\
\text { Information }\end{array}$} & \multicolumn{2}{|c|}{$\begin{array}{l}\text { To Access Information for } \\
\text { Making Note }\end{array}$} & \multicolumn{2}{|c|}{$\begin{array}{l}\text { To Access Information for } \\
\text { Assignment }\end{array}$} & \multicolumn{2}{|c|}{$\begin{array}{l}\text { To Access Information for } \\
\text { Leisure and Recreational } \\
\text { Purposes }\end{array}$} & \multirow[t]{2}{*}{ Total } \\
\hline & F & $\%$ & $\mathbf{F}$ & $\%$ & F & $\%$ & F & $\%$ & \\
\hline 100 & 20 & 40 & 8 & 16 & 20 & 40 & 2 & 4 & 50 \\
\hline 200 & 22 & 50 & 4 & 9 & 18 & 41 & 0 & 0 & 44 \\
\hline 300 & 30 & 56 & 4 & 7 & 16 & 30 & 4 & 7 & 54 \\
\hline 400 & 24 & 43 & 18 & 32 & 12 & 21 & 2 & 4 & 56 \\
\hline Total & 96 & 37 & 40 & 15 & 118 & 45 & 8 & 3 & 262 \\
\hline
\end{tabular}

Table 7 revealed that $118(45 \%)$ of the respondents use catalogue to access information for assignment, followed by those that use it to retrieve information for research 96 (37\%). It could be concluded that majority of the respondents used the library for research work rather than for leisure and recreational purposes. This agrees with the findings of Oghenekaro that $94(37.5 \%)$ of the respondents used it for research purpose, 66 (26.3) used it for enquiry, while others used it for bibliographic record supply, document delivery and others[1].

\subsection{Challenges Associated with the Use of Library Catalogue}

The respondents were given multiple options to indicate as many as applicable the challenges associated with the use of library catalogue in the university libraries. The results are presented in Table 8.

Table 8. Challenges Associated with the Use of Library Catalogue.

\begin{tabular}{|c|c|c|c|c|c|c|c|c|c|c|c|c|}
\hline \multirow{2}{*}{ Variables } & \multicolumn{2}{|c|}{100 Level } & \multicolumn{2}{|c|}{200 Level } & \multicolumn{2}{|c|}{300 Level } & \multicolumn{2}{|c|}{400 Level } & \multicolumn{2}{|c|}{500 Level } & \multicolumn{2}{|c|}{ Total } \\
\hline & $\mathbf{F}$ & $\%$ & $\mathbf{F}$ & $\%$ & $\mathbf{F}$ & $\%$ & $\mathbf{F}$ & $\%$ & $\mathbf{F}$ & $\%$ & $\mathbf{F}$ & $\%$ \\
\hline $\begin{array}{l}\text { 1. Inability to locate materials on the shelves, indicated in the } \\
\text { catalogue as being available }\end{array}$ & 16 & 32 & 12 & 27 & 16 & 30 & 14 & 26 & 0 & 0 & 58 & 22 \\
\hline 3. Power outage causing frustration when accessing OPAC & 2 & 4 & 4 & 9 & 6 & 11 & 0 & 0 & 0 & 0 & 12 & 5 \\
\hline 4. Time wasting when using card catalogue & 6 & 12 & 4 & 9 & 6 & 11 & 2 & 4 & 0 & 0 & 18 & 7 \\
\hline 5. Cost of access to OPAC, outside school & 0 & 0 & 0 & 0 & 0 & 0 & 0 & 0 & 0 & 0 & 0 & 0 \\
\hline 7. Lack of adequate time to search for information & 12 & 24 & 10 & 23 & 6 & 11 & 4 & 7 & 2 & 3 & 34 & 13 \\
\hline $\begin{array}{l}\text { 8. Poor computer skills hindering navigation when searching } \\
\text { OPAC }\end{array}$ & 4 & 8 & 6 & 14 & 6 & 11 & 26 & 48 & 54 & 90 & 96 & 37 \\
\hline $\begin{array}{l}\text { 9. Difficulty in getting information from card catalogue } \\
\text { because of poor retrieval skills }\end{array}$ & 2 & 4 & 8 & 18 & 4 & 7 & 2 & 4 & 2 & 3 & 18 & 7 \\
\hline Total & 50 & 100 & 44 & 100 & 54 & 100 & 54 & 100 & 60 & 100 & 262 & 100 \\
\hline
\end{tabular}

Table 8 focused on the challenges associated with catalogue use for information retrieval. Higher number of the respondents indicated poor computer skills hindering navigation when searching OPAC 96 (37\%) and inability to locate materials on the shelves, indicated in the catalogue as being available $58(22 \%)$ were the challenges affecting the use of catalogue as an information retrieval tools. This indicates that good of the respondents had difficulties using the library catalogue because the respondents lack sound ICT skills that could enable them use the OPAC. ICT skill is needed by the respondents to be able to browse the library OPAC. Again, the later challenge could be attributed to lack proper shelf reading by the library staff, which made users not to locate material indicated available in the library by the catalogue and not visible on its shelf.

This finding corroborates with that of Ogbole \& Morayo which revealed that $(41.1 \%)$ of the respondents rarely use OPAC. The difficult interface of OPAC poses a big challenge to undergraduates who are the target users of OPAC in any academic library. Users then turn away from the library to use external tools that they feel is more convenient and easy to use such as online search engines when they have information needs [2]. Again with that of [Ogunniyi \& Efosa whose study concluded that the problem of catalogue use is associated with lack of knowledge on how to use the library 
catalogue [11]. The finding was completely different from that of Onuoha, Umahi, \& Bamidele where respondents faced problems associated mostly with orientation and unstable power supply in UNAAB and also at RUN where the challenge was mostly associated with computer supply and lack of orientation for students[13].

\section{Conclusion}

The study revealed that majority of the university library users were male. It is disturbing to discover from the study, that most of the respondents were aware of the card catalogues as access and retrieval tool for searching for information resources in the library. Higher number of them got their awareness through library staff and above average used the library catalogue regularly. Unfortunately, most of the respondents were yet to be conscious of the existence of the OPAC, do not understand its operations and rarely use the service despite the huge investment of library resources in the production. Therefore, proper orientation and awareness campaign should be done to address this ugly situation. It could be concluded that majority of the respondents used the library for research work rather than for leisure and recreational purposes. Another source of frustration was reasonable number of the respondents indicated poor computer skills hindering navigation when searching OPAC and inability to locate materials on the shelves, indicated in the catalogue as being available were the challenges affecting the use of catalogue as an information retrieval tools.

\section{Recommendations}

Considering the important roles library catalogue plays in effective and efficiency use of library information resources, the research recommends the following to improve the use of library catalogue for information access and retrieval:

a. The library management should organize a periodic user education programmes for the undergraduate users. This will enable them gain the needed skills to use the library catalogue maximally when searching for information resources.

b. Librarians should organize orientation and sensitization programmes that will create awareness, and encourage the university community to effectively use OPAC to ensure proper use of library information resources. Because most challenges associated with the use of the OPAC often have to do with lack of ICT skills on how to make use of it.

c. Guidelines on how to use catalogue and library in general should be prepared and issued to registered users.

d. Regular shelf reading should be done so as to establish right contact between library users and library materials and avoid misplacement or wrong shelving of information resources.

\section{References}

[1] Oghenekaro, A. P. (2018) Use of Library Catalogue in Nigerian University Libraries: A Focus on Redeemer's University Library. Open Access Library Journal, 5: e4532. Pp: 1-10. Retrieved from https://doi.org/10.4236/oalib.1104532 on 6/8/2019

[2] Ogbole, J. O. \& Morayo, A. (2017). Factors Affecting Online Public Access Catalogue Provision And Sustainable Use By Undergraduates In Two Selected University Libraries In Ogun And Oyo States, Nigeria. IOSR Journal of Research \& Method in Education (IOSR-JRME) 7 (4), $P P$ 14-25. Retrieved from www.iosrjournals.org, on 22/7/2019.

[3] Aina, L. O. (2004). Library and Information Science Text for Africa. Ibadan, Third Word Information Services Limited. Pp: $1-365$

[4] Ruzegea, M. (2012). Usability of OPAC Interface Features: The Perspectives of Postgraduate Students at International Islamic University Malaysia. Library Philosophy \& Practice (e-journal).

[5] Atanda, L. A. \& Ugwulebo, J. E. (2017). Awareness, Access and Utilization of Library Catalogue by Undergraduate Students of the College of Law, Osun State University Osogbo, Osun State, Nigeria. International Journal of Library and Information Science, 9 (11), pp: 115-121. Retrieved from $\mathrm{http}: / /$ www.academicjournals.org/IJLIS \& \& DOI: 10.5897/IJLIS2017.0785 on 6/8/2019.

[6] Kumar, S. \& Vohra, R. (2011). Use of Online Public Access Catalogue in Guru Nanak Dev University library, Amritsar: a study. SRELS Journal of Information Management, 48 (5), pp: 519-28.

[7] Kumar, A. (2017). Awareness and Use of Online Public Access Catalogue Services among the Students of Department of English, Mathematics and Commerce of Kurukshetra University, Kurukshetra, Haryana: India. International Journal of Digital Library Services, 7 (2), pp. 51-61. Retrieved from www.ijodls.in on 6/8/2019

[8] Amkpa, S. A. \& Iman, A. I. (2011) Library Instruction Programme as a Correlate of Student Catalogue Use in Colleges of Education Libraries. Library Philosophy and Practice (e-journal) 456. Retrieved from http://digitalcommons.unl.edu/libphilprac/456 on 6/8/2019

[9] Okorafor, C. N. (2006) Using Library Catalogue as Access to Academic Library Col-lection in Nigeria. Journal of the Nigerian Library Association, Imo State Chapter, 4, 37-43.

[10] Aguolu, C. C. \& Aguolu, I. E. (2002). Libraries and Information Management in Nigeria: Seminal Essays on Themes and Problems. Maiduguri, Nigeria: Ed-Linform Services. pp. 383-399.

[11] Clifford, I. B. \& Zaccus, O. Y. (2015) Users Attitude towards the Use of Library Catalogue in Two Selected University Libraries in South West Nigeria, Journal of Applied Information Science and Technology, 8 (1). pp: 44-55. Retrieved https://www.researchgate.net/publication/276284002 from $22 / 7 / 2019$ 
[12] Fabunmi, O. M. \& Asubiojo, B. O. (2013). Awareness and Use of Online Public Access Catalogue by Students of Obafemi Awolowo University, Ile-Ife, Nigeria. Library Philosophy and Practice (e-journal). Paper 922. Retrieved from http://digitalcommons.unl.edu/libphilprac/922 on $22 / 7 / 2019$

[13] Onuoha, U. D., Umahi, F. O. \& Bamidele, I. A. (2013). Use and satisfaction with online public access catalogue in selected university libraries in Ogun State, Nigeria, Information and Knowledge Management, 3 (11), pp: 1-6. Retrieved from www.iiste.org on 6/8/2019
[14] Creative Research Systems survey software. Sample Size Calculator, Accessed https://www.surveysystem.com/sscalc.htm

https://www.calculator.net/sample-sizecalculator.html?type $=1 \& \mathrm{cl}=95 \& \mathrm{ci}=5 \& \mathrm{pp}=50 \& \mathrm{ps} \quad=920 \& \mathrm{x}=6$ $6 \& y=21$ on 29 th $/ 07 / 2019$ 